\title{
Species-specific identification of Mycobacterium bovis by PCR
}

\author{
Juan G. Rodriguez, Gloria A. Mejia, Patricia Del Portillo, \\ Manuel E. Patarroyo and Luis A. Murillo
}

Author for correspondence: Patricia Del Portillo.e-mail: inmunol3@colcig3.colciencias.gov.co

Instituto de Inmunologia, Hospital San Juan de Dios, Universidad Nacional de Colombia, Carrera 10 \# 1-01, Santafé de Bogotá, Colombia

\begin{abstract}
The Random Amplified Polymorphic DNA (RAPD) technique was used in the identification of a species-specific fragment of Mycobacterium bovis. A fragment of approximately $\mathbf{5 0 0}$ bp was amplified from the genome of 15 different $\boldsymbol{M}$. bovis strains, including $\boldsymbol{M}$. bovis BCG Pasteur, but was shown to be absent in $\mathbf{2 6}$ different mycobacteria and $\mathbf{2 0}$ different clinical isolates of Mycobacterium tuberculosis. When the fragment was used as a probe in a Southern blot analysis, several radioactive bands common to $M$. tuberculosis and $M$. bovis were observed. However, this fragment hybridized specifically to a 2900 bp EcoRI fragment in the $M$. bovis genome, but failed to hybridize in either $\boldsymbol{M}$. tuberculosis or $\boldsymbol{M}$. avium chromosomal DNA. Based on a partial nucleotide sequence of the 500 bp fragment, two oligonucleotide primers were designed and a PCR assay was developed. Using purified mycobacterial DNA samples, only $\boldsymbol{M}$. bovis and $\boldsymbol{M}$. bovis BCG rendered a unique amplification band. This PCR assay is able to detect down to $10 \mathrm{fg}$ purified $M$. bovis DNA, which corresponds roughly to two bacilli. The assay is also useful for identifying the bacilli directly from uncultured biological samples, such as milk.
\end{abstract}

Keywords: RAPD, PCR, diagnosis, Mycobacterium bovis

\section{INTRODUCTION}

Bovine tuberculosis is currently an important zoonosis worldwide, and the possibility of human infection with Mycobacterium bovis cannot be ignored. Although scarce epidemiological information is available, $M$. bovis has been reported to have caused between 6 and $30 \%$ of the cases of human tuberculosis (TB) in the USA before milk pasteurization (Karlson \& Carr, 1970). It is also the cause of $6.3 \%$ of the bacteriologically confirmed cases of tuberculosis in Western Ireland (Cormican \& Flynn, 1992). Brett \& Humble (1991), in a study conducted in New Zealand, showed an increase of bovine TB cases between $1983(3.7 \%)$ and $1989(14.6 \%)$. Despite the fact that in some regions in Latin America human TB diagnosis is still based on smear examination, a report has estimated that approximately 7000 new TB cases per year are caused by infection from $M$. bovis (PAHO, 1991).

To prevent human disease, a successful scheme of control and eradication of $M$. bovis infection in cattle is essential.

Abbreviation: RAPD, Random Amplified Polymorphic DNA.
However, eradication campaigns have been hampered by the low sensitivity and specificity of the bovine skin test currently used for the detection of infected animals (Radford et al., 1988; Collins \& Grange, 1983). The lack of an accurate diagnostic method for the detection of the causative agent in cattle leads not only to an enhanced risk in public health programmes, but also to economical loss for the cattle industry.

Speciation of mycobacteria for diagnostic purposes, among them $M$. bovis, has always been difficult. Attempts to develop more accurate serological diagnostic methods have been carried out (Fifis et al., 1989; Harboe et al., 1990; Griffin et al., 1991), but have failed to show sufficient sensitivity and specificity, due mainly to the high antigenic cross-reactivity among mycobacteria (Daniel \& Janicki, 1978; Harboe \& Nagai, 1984). Recently, molecular biology techniques have proved to be of great value for the diagnosis of mycobacteria and also to distinguish between mycobacterial species (Franco et al., 1989; Zainuddin \& Dale, 1989; Haas et al., 1993); the polymerase chain reaction (PCR) has been particularly useful for these purposes (Cook et al., 1994; Noordhoek et al., 1994; Mizrahi et al., 1993; Telenti et al., 1993). Most of 
these PCR assays amplify fragments from the so-called Mycobacterium tuberculosis complex, and thus cannot distinguish between infections caused by $M$. tuberculosis and those caused by $M$. bovis. Although specific identification of $M$. bovis has been reported, the procedure requires the amplification of fragments common to all mycobacteria and the subsequent specific identification using radiolabelled probes or restriction endonuclease patterns (Barry et al., 1993; Hance et al., 1989; Collins \& de Lisle, 1985).

As a consequence of the high antigenic cross-reactivity and the close genomic relationship among mycobacteria, the identification of a species-specific sequence is not an easy task (Eisenach et al., 1986; Baess, 1979, 1983). We have previously reported a PCR assay for the diagnosis of human tuberculosis (Del Portillo et al., 1991) based on a M. tuberculosis species-specific sequence (Parra et al., 1991). In the present paper, we describe the use of the Random Amplified Polymorphic DNA (RAPD) technique (Williams et al., 1990; Welsh \& McClelland, 1990) for the identification of a species-specific $M$. bovis genomic fragment, and the development of a single-step PCR assay that can be used as a powerful tool in epidemiological studies, which would allow an efficient control of bovine tuberculosis.

\section{METHODS}

Bacterial strains. The sources of mycobacterial strains used are listed in Table 1. Mycobacteria were grown in Sauton or Lowenstein-Jensen medium, harvested and stored at $4{ }^{\circ} \mathrm{C}$ until used. $M$. bovis strains were isolated from infected animals in different regions around the country. $M$. tuberculosis clinical isolates were obtained from the Bacteriology Laboratory, Hospital San Juan de Dios. All strains were typed by conventional microbiological and biochemical tests.

Chromosomal DNA extraction. Large-scale DNA extraction from both fast- and slow-growing mycobacterial species was performed as previously described by Del Portillo et al. (1991). For small-scale purification of DNA, a loopful from a grown colony was resuspended in TE $(10 \mathrm{mM}$ Tris $/ \mathrm{HCl}, \mathrm{pH} 8.0$, $1 \mathrm{mM}$ EDTA) and washed three times with the same buffer. The bacilli were incubated for $1 \mathrm{~h}$ at $37^{\circ} \mathrm{C}$ in the presence of lysozyme $\left(2 \mathrm{mg} \mathrm{ml}^{-1}\right)$. Bacterial membranes were disrupted by increasing the temperature to $60^{\circ} \mathrm{C}$ and the addition of SDS and proteinase $\mathrm{K}$ (Bethesda Research Laboratory) to a final concentration of $1 \%(\mathrm{w} / \mathrm{v})$ and $250 \mu \mathrm{g} \mathrm{ml}^{-1}$, respectively. After $1.5 \mathrm{~h}$, DNA was extracted with phenol/chloroform and precipitated with 0.6 vol. 2-propanol. The pellet was washed with $70 \%(\mathrm{v} / \mathrm{v})$ ethanol and resuspended in $30-50 \mu \mathrm{l}$ distilled water; $10 \mu$ l was used for the RAPD technique, or for the specific PCR assay.

RAPD primers. The oligonucleotide sequence of the primers used for the RAPD technique are listed in Table 2. The oligonucleotide sequences were designed according to the GC content of mycobacterial genomes, and using the Oligo version 4.0 program (National Biosciences). The primers were synthesized by the solid phase phosphite triester method on a Pharmacia LKB Gene Assembler Special. Purification and concentration of each primer was carried out as published elsewhere by Maniatis et al. (1982).

Amplification by the RAPD technique. The reactions were
Table 1. Reference strains used for the RAPD and PCR

\begin{tabular}{|c|c|}
\hline Strain & Source* \\
\hline M. bovis & ATCC 19210 \\
\hline M. bovis BCG Pasteur & ATCC 27291 \\
\hline M. bovis & Cow isolate (Colombia) \\
\hline M. bovis & Clinical isolate (Spain) \\
\hline M. tuberculosis H37Rv & TMC 102 \\
\hline M. tuberculosis $\mathrm{H} 37 \mathrm{Ra}$ & ATCC 25177 \\
\hline M. simiae & ATCC 25275 \\
\hline M. scrofulaceum & ATCC 19981 \\
\hline M. gordonae & ATCC 14470 \\
\hline M. nonchromogenicum & TMC 1481 \\
\hline M. triviale & ATCC 23290 \\
\hline M. intracellulare & ATCC 13950 \\
\hline M. phlei & TMC 1548 \\
\hline M. vaccae & ATCC 15483 \\
\hline M. diernboferi & ATCC 19340 \\
\hline M. flavescens & TMC 1541 \\
\hline M. fortuitum & ATCC 6842 \\
\hline M. ulcerans & ATCC 19423 \\
\hline M. chelonae subsp. chelonae & A'TCC 35752 \\
\hline M. chelonae subsp. abscessus & ATCC 19977 \\
\hline M. avium & ATCC 25291 \\
\hline M. kansasii & TMC 1204 \\
\hline M. africanum & A'TCC 25420 \\
\hline Actinomyces sp. & ATCC 15214 \\
\hline Rbodococcus sp. & ATCC 12485 \\
\hline Nocardia asteroides & ATCC 3308 \\
\hline M. gastri & TMC 1456 \\
\hline M. smegmatis & ATCC 19420 \\
\hline M. szulgai & TMC 1328 \\
\hline M. terrae & TMC 1450 \\
\hline M. parafortuitum & ATCC 19686 \\
\hline M. marinum & TMC 1218 \\
\hline M. microti & ATCC 19422 \\
\hline
\end{tabular}

* ATCC, American Type Culture Collection; TMC, Trudeau Mycobacterial Culture Collection.

performed in a final volume of $50 \mu$ containing $10 \mu \mathrm{l}$ DNA from the different mycobacterial strains, $1 \times$ reaction buffer (Gene amp kit, Perkin Elmer Cetus), $2.5 \mathrm{U}$ Taq polymerase, $0.2 \mathrm{mM}$ of each deoxynucleoside triphosphate, and 75 pmol of each primer. The reaction was carried out on a Perkin Elmer DNA thermal cycler. The reaction was subjected to 30 cycles of amplification with a denaturation step of $94^{\circ} \mathrm{C}$ for $1 \mathrm{~min}$, an annealing step of $30 \mathrm{~s}$ at the melting temperature $\left(\mathrm{T}_{\mathrm{m}}\right.$, Table 2$)$ of the primer used, and an extension step of $1 \mathrm{~min}$ at $72{ }^{\circ} \mathrm{C}$.

Analysis of the RAPD products. An aliquot $(5 \mu \mathrm{l})$ from the RAPD assay was analysed by gel electrophoresis in a $1 \%(\mathrm{w} / \mathrm{v})$ agarose gel. DNA was visualized by staining with ethidium bromide $\left(0.5 \mu \mathrm{g} \mathrm{ml}^{-1}\right.$; Sigma) and gels were photographed on a UV transilluminator. The amplified products were blotted onto Z-probe membranes (Bio-Rad) for hybridization analysis.

The specific fragment amplified by the RAPD technique, approximately $500 \mathrm{bp}$ long, was purified from agarose gels 
Table 2. Primers used for RAPD assay and $M$. bovis detection

\begin{tabular}{|llcc|}
\hline Primer & \multicolumn{1}{c|}{ Nucleotide sequence } & $\begin{array}{c}\mathbf{T}_{\mathbf{m}} \\
\left({ }^{\circ} \mathbf{C}\right)^{*}\end{array}$ & $\begin{array}{c}\text { \%GC } \\
\text { at }\end{array}$ \\
\hline JB1 \\
JB1 & 5' CGTCCGCCGA & 36 & $46 \cdot 8$ \\
JB2 & 5' CGTCCGCTGA & 34 & $42 \cdot 7$ \\
JB3 & 5' CCTCTCAGCA & 32 & $38 \cdot 6$ \\
JB4 & 5' CCTATCAGCA & 30 & $34 \cdot 5$ \\
JB5 & 5' CCTATCATCA & 28 & $30 \cdot 4$ \\
JB21 & 5' TCGTCCGCTGATGCAAGTGC & 64 & 68 \\
JB22 & 5' CGTCCGCTGACCTCAAGAAG & 64 & 68 \\
\hline
\end{tabular}

${ }^{*} \mathrm{~T}_{\mathrm{m}}\left({ }^{\circ} \mathrm{C}\right)$, Melting temperature $2(\mathrm{~A}+\mathrm{T})+4(\mathrm{G}+\mathrm{C})$.

$\dagger \% \mathrm{GC}$ at $\mathrm{T}_{\mathrm{m}}$, melting temperature \%GC (Baldino et al., 1989).

using a Geneclean kit (Bio 101). Amplified fragment (10 ng) was labelled with the Rediprime kit (Amersham) using $\left[\alpha_{-}^{32} \mathrm{P}\right] \mathrm{dCTP}$ (Amersham).

The Z-probe membranes containing the RAPD products from the different mycobacterial strains were hybridized with the radiolabelled probe $\left(1 \times 10^{6}\right.$ c.p.m. ml $\left.{ }^{-1}\right)$ at $42{ }^{\circ} \mathrm{C}$ overnight in a solution containing $50 \%(\mathrm{v} / \mathrm{v})$ formamide, $0.12 \mathrm{M} \mathrm{Na}_{2} \mathrm{HPO}_{4}$, $\mathrm{pH} 7 \cdot 2,0.25 \mathrm{M} \mathrm{NaCl}$, and $7 \%$ (w/v) SDS. After hybridization, the membrane was washed for $15 \mathrm{~min}$ in $2 \times \mathrm{SSC}(1 \times \mathrm{SSC}$ is $0 \cdot 15 \mathrm{M} \mathrm{NaCl}, 0.015 \mathrm{M}$ sodium citrate) $/ 0 \cdot 1 \% \mathrm{SDS}$ at $42{ }^{\circ} \mathrm{C}$; $30 \mathrm{~min}$ in $1 \times \mathrm{SSC} / 0.1 \% \mathrm{SDS}$ at $42{ }^{\circ} \mathrm{C}$, and finally for $30 \mathrm{~min}$ in $0 \cdot 1 \times \mathrm{SSC} / 0 \cdot 1 \%$ SDS at $65^{\circ} \mathrm{C}$, and exposed overnight to Kodak $\mathrm{X}$-Omat film at $-70^{\circ} \mathrm{C}$.

For a genomic Southern blot analysis, $5 \mu \mathrm{g} M$. tuberculosis, $M$. bovis and $M$. avium DNAs were digested to completion with EcoRI. The hybridization was carried out as described above.

Cloning and sequencing of the specific fragment. The purified fragment was cloned into the pCR 1000 cloning plasmid (Invitrogene) and nucleotide sequencing of clone pLD 1 was carried out using T7 and M13 forward primer with the Sequenase kit from USB (Sanger et al., 1977).

Amplification by PCR. Based on the specific 500 bp fragment partial nucleotide sequence, a pair of primers was designed for use in a specific PCR assay (Table 2). Reaction conditions were optimized for 30 cycles to be performed as follows: a denaturation step at $94^{\circ} \mathrm{C}$ for $1 \mathrm{~min}$, an annealing step at $68^{\circ} \mathrm{C}$ for $1 \mathrm{~min}$, and a synthesis step at $72^{\circ} \mathrm{C}$ for $1 \mathrm{~min}$.

Specificity and sensitivity of the PCR. In order to determine the reaction specificity, $50 \mathrm{ng}$ different mycobacterial DNAs were used as a target for the reaction. The amplified products were analysed by ethidium-bromide-stained gels and by Southern blot analysis. Studies regarding the specificity of the reaction with non-related mycobacterial species were performed in spiked milk as follows. A loopful from a grown colony was resuspended in $1 \mathrm{ml}$ crude milk. The samples were heated at $80^{\circ} \mathrm{C}$ for $10 \mathrm{~min}$, in order to inactivate the micro-organisms, and centrifuged at $12500 \mathrm{~g}$ for $15 \mathrm{~min}$. The supernatant was discarded and the pellet treated in the same manner as described for small-scale DNA purification. The amplified products were analysed by electrophoresis in $1 \%(\mathrm{w} / \mathrm{v})$ ethidium-bromidestained agarose gels.

In order to establish the limit of sensitivity of the PCR assay, serial dilutions of $M$. bovis DNA were used as targets for the reaction. The amplification products were analysed as described above.

\section{RESULTS \\ Identification of the species-specific fragment}

With the aim of recognizing a $M$. bovis-specific genomic fragment, RAPD assays were conducted using DNA from both $M$. bovis and the closely related species $M$. tuberculosis. The RAPD primers were used alone or in different combinations (Table 2). Although several amplification products were visualized in ethidium-bromidestained agarose gels, the majority were common to both mycobacterial species (data not shown). When primer JB2 was used alone, an amplification band of approximately $500 \mathrm{bp}$ long was obtained, which was clearly present in three different $M$. bovis isolates but absent in the $M$. tuberculosis H37Rv strain (Fig. 1). To determine if the fragment was specific to $M$. bovis and absent in the genomes of different mycobacterial strains, DNA isolated from 22 mycobacteria and 3 different $M$. bovis isolates was used in the RAPD assay with primer JB2. As can be seen in Fig. 2(a), several RAPD amplification products are obtained from the diverse genomic DNAs tested, thus making it difficult to clearly recognize the presence or absence of the specific $500 \mathrm{bp}$ fragment. The amplification products shown in Fig. 2(a) were therefore blotted onto Z-probe membranes and hybridized with the radiolabelled $500 \mathrm{bp}$ fragment obtained from the RAPD assay of $M$. bovis DNA. A positive hybridization signal was observed

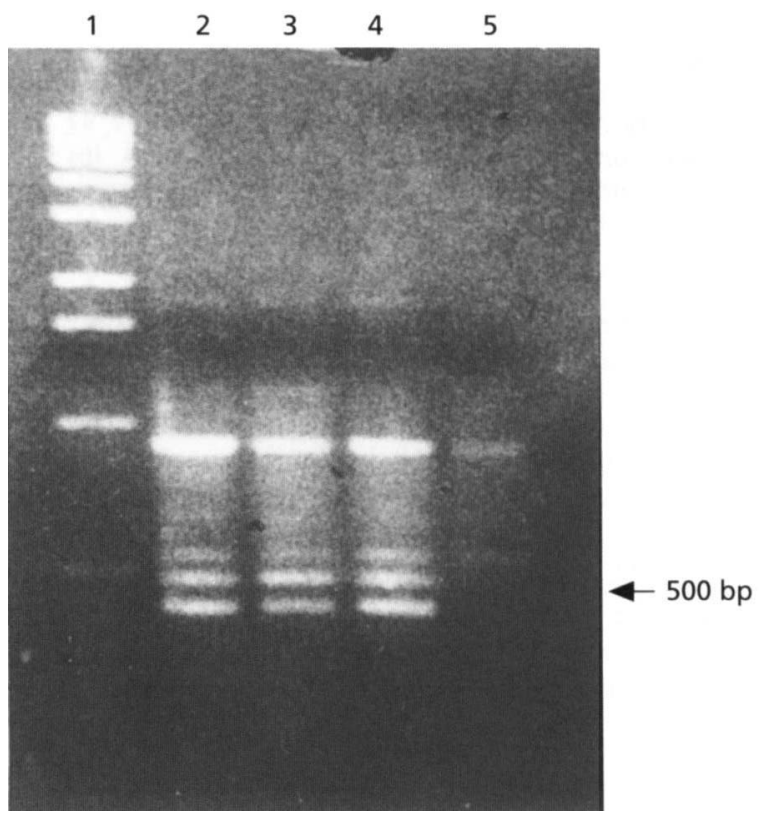

Fig. 1. Identification of the $M$. bovis-specific fragment. Agarose gel electrophoresis of the RAPD assay products of genomic DNA from $M$. bovis and $M$. tuberculosis using primer JB2. Lanes: 1, $1 \mathrm{~kb}$ ladder molecular size markers (Gibco-BRL); $2, M$. bovis ATCC 19210; 3, M. bovis BCG Pasteur substrain ATCC 27291; 4, M. bovis wild-type; 5, M. tuberculosis H37Rv TMC 102. 
(a)

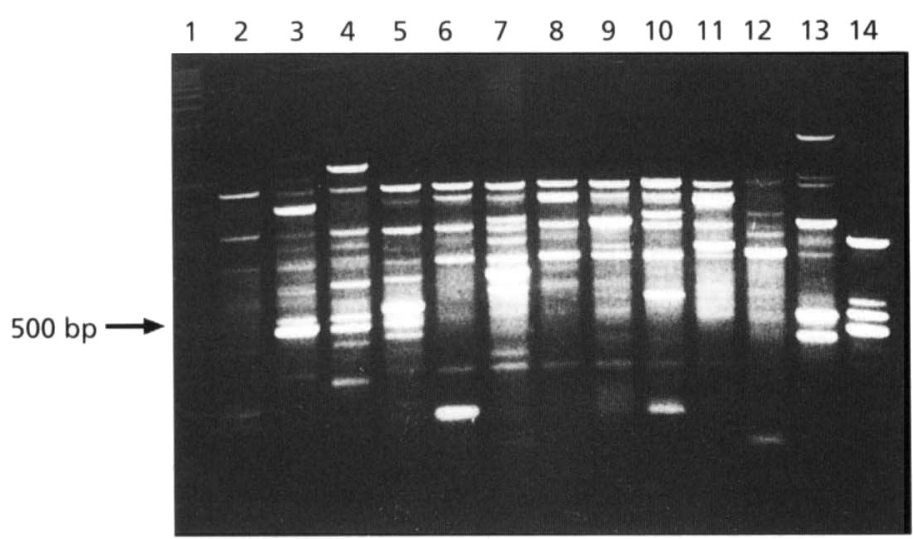

15161718192021222324252627282930

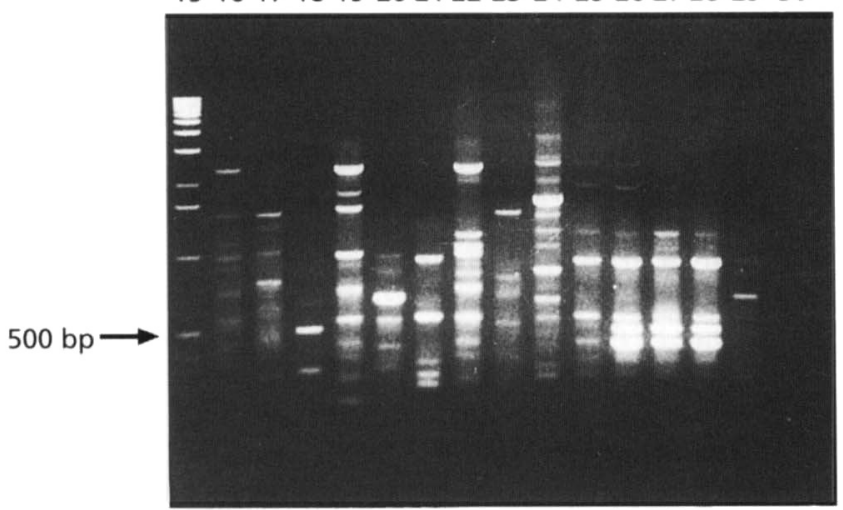

(b)

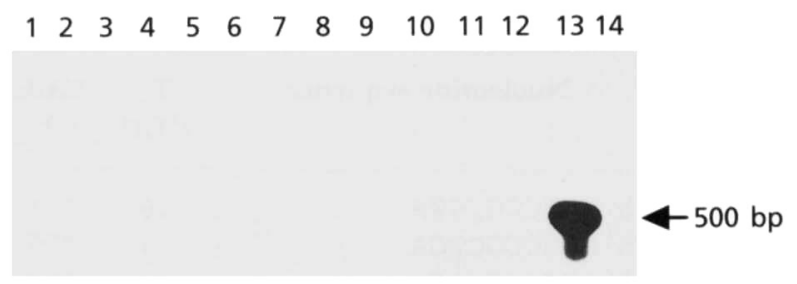

15161718192021222324252627282930

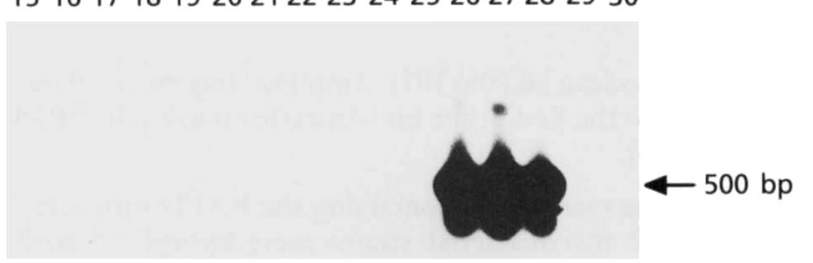

Fig. 2. RAPD analysis of different mycobacterial strains. (a) Agarose gel electrophoresis ( $1 \%$ gel). Lanes: $1,1 \mathrm{~kb}$ ladder molecular size markers; $2, M$. simiae; $3, M$. scrofulaceum; $4, M$. gordonae; $5, M$. nonchromogenicum; $6, M$. triviale; $7, M$. intracellulare; $8, M$. phlei; 9, $M$. vaccae; $10, M$. diernhoferi; $11, M$. flavescens; $12, M$. fortuitum; $13, M$. ulcerans; $14, M$. bovis; 15 , molecular size markers; $16, M$. chelonae subsp. chelonae; $17, M$. chelonae subsp. abscessus; $18, M$. avium; 19 , M. kansasii; 20, M. gastri; 21, M. smegmatis; 22, M. szulgai; 23, $M$. terrae; $24, M$. parafortuitum; $25, M$. tuberculosis H37Rv TMC 102; 26, M. bovis ATCC 19210; 27, M. bovis BCG Pasteur substrain ATCC 27291; 28, M. bovis wild-type; $29, M$. marinum; 30, negative control without DNA. (b) Southern blot analysis using DNA transferred from gels in Fig. 2(a) and hybridized with the 500 bp radiolabelled fragment obtained from the RAPD assay using $M$. bovis DNA.

only with the genomes of the $M$. bovis strains and not with any of the other DNAs used (Fig. 2b).

The radiolabelled fragment was also used as a probe in a Southern blot using EcoRI-digested genomic DNA from $M$. bovis, $M$. tuberculosis and $M$. avium. The autoradiography revealed homologous regions between $M$. bovis and $M$. tuberculosis. However, the 500 bp fragment allowed the identification of a polymorphic region of $2900 \mathrm{bp}$ in the $M$. bovis genome which was not homologous in the genomes of $M$. tuberculosis and $M$. avium (Fig. 3).

\section{Development of the M. bovis-specific PCR}

The nucleotide sequences of the primers used in this study are shown in Table 2 . The $M$. bovis-specific $500 \mathrm{bp}$ fragment was cloned in the pCR1000 cloning vector and the ends of the insert sequenced. Based on the partial nucleotide sequence of the recombinant clone pLD 1, primers JB21 and JB22 were synthesized. A PCR assay using these two primers was optimized using purified $M$. bovis and $M$. tuberculosis H37Rv DNA, such that after 30 amplification cycles a fragment of approximately $495 \mathrm{bp}$ was detected exclusively from $M$. bovis DNA. In this assay, no other amplification products were observed from either the $M$. tuberculosis or the $M$. bovis genomes (data not shown).

\section{Specificity and sensitivity of the PCR}

The specificity of the PCR assay was examined using DNA isolated from 14 different reference mycobacterial species. The 495 bp amplification product was found only with $M$. bovis DNA. Representative samples tested by PCR amplification and Southern blot analysis of the products are shown in Fig. 4. To demonstrate that this PCR assay could be useful in distinguishing between $M$. tuberculosis and $M$. bovis, $20 \mathrm{M}$. tuberculosis clinical isolates and $11 M$. bovis isolates were amplified with the JB21 and 
$2 \quad 3 \quad 4$
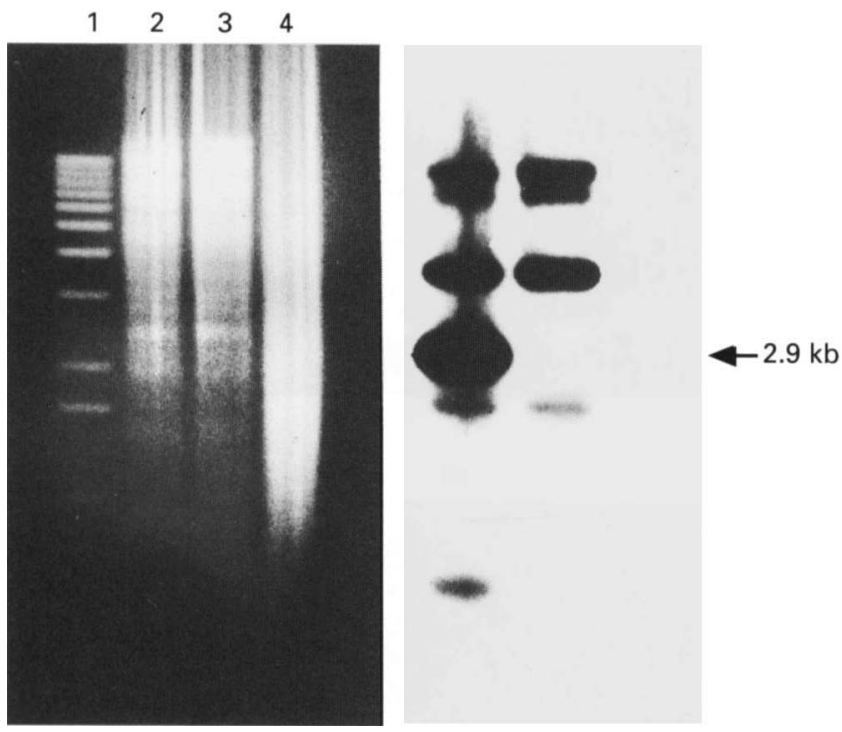

Fig. 3. Agarose gel electrophoresis and corresponding Southern blot analysis of EcoRI restriction of $M$. bovis, $M$. tuberculosis and $M$. avium genomic DNAs. Lanes: $1,1 \mathrm{~kb}$ ladder molecular size markers; $2, M$. bovis ATCC 19210; 3, M. tuberculosis H37Rv TMC 102; 4, M. avium ATCC 25291.

JB22 primers. As can be seen in Fig. 5, the PCR assay is shown to amplify a fragment exclusively from the $M$. bovis genomes, confirming the results obtained with the ref- erence strains. These same strains were assayed by a $M$. tuberculosis-specific PCR test (Del Portillo et al., 1991), which, as expected, rendered a 396 bp amplification band with the $20 M$. tuberculosis strains (data not shown).

To demonstrate that the PCR assay could be carried out directly on biological samples, $1 \mathrm{ml}$ crude milk was spiked with $M$. bovis or unrelated bacteria commonly isolated from milk (Table 1). PCR amplification of the $495 \mathrm{bp}$ fragment was obtained only from milk spiked with $M$. bovis but not of that spiked with other bacteria, demonstrating not only that the assay is specific for $M$. bovis, but also that milk components do not inhibit the PCR reaction (data not shown).

The sensitivity of the PCR assay with primers JB21 and JB22 was determined by adding decreasing amounts of $M$. bovis DNA to the reaction vials. Down to $10 \mathrm{fg}$ DNA could be amplified reproducibly to give a clearly detectable band in ethidium-bromide-stained agarose gels (data not shown).

\section{DISCUSSION}

A rational approach of preventing human infection by $M$. bovis and to reduce its economical impact due to diseased cattle involves the implementation of eradication programmes. In order to achieve this objective, a rapid, specific and reliable diagnostic method for the timely detection of $M$. bovis in infected animals is essential. In spite of the high DNA homology among genomes of the various mycobacterial species, and in particular of those belonging to the $M$. tuberculosis complex, which include

(a)

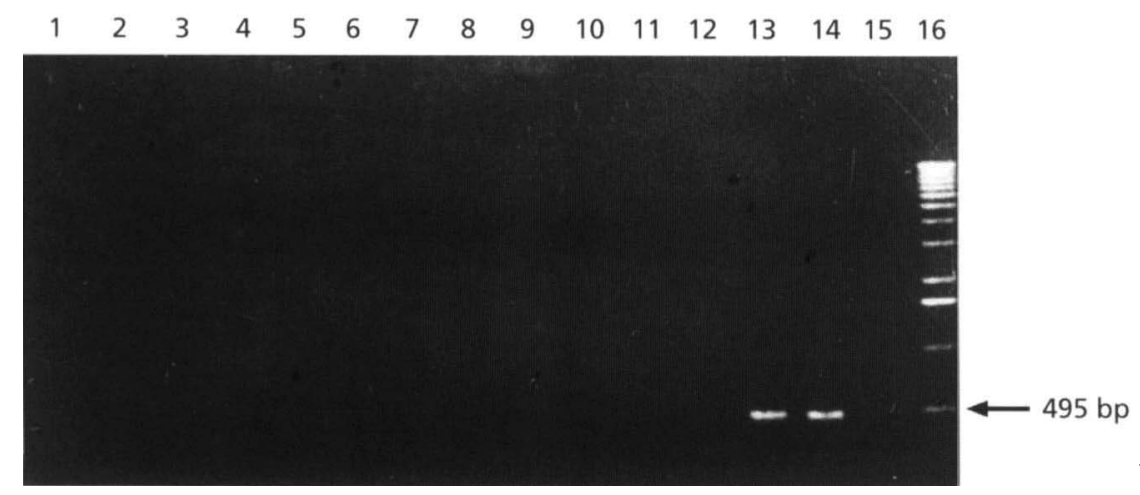

(b)

$\begin{array}{llllllllllllllll}1 & 2 & 3 & 4 & 5 & 6 & 7 & 8 & 9 & 10 & 11 & 12 & 13 & 14 & 15 & 16\end{array}$

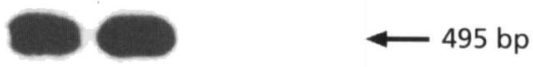

Fig. 4. Specificity of the $P C R$ assay. (a) Amplification of DNA from various mycobacterial strains. Lanes: $1, M$. microti 2, M. smegmatis; $3, M$. scrofulaceum; 4. $M$. intracellulare; $5, M$. marinum; 6, M. africanum; 7, M. avium; 8, M. fortuitum; $9, M$. gordonae; $10, M$. phlei $11, M$. tuberculosis H37Ra; 12, M. tuberculosis H37Rv TMC 102; 13, M. bovis ATCC 19210; 14, $M$. bovis BCG Pasteur substrain ATCC 27291; 15, negative control without DNA; $16,1 \mathrm{~kb}$ ladder molecular size markers. (b) Autoradiograph of samples from Fig. 4(a) hybridized with the $500 \mathrm{bp}$ radiolabelled fragment. 

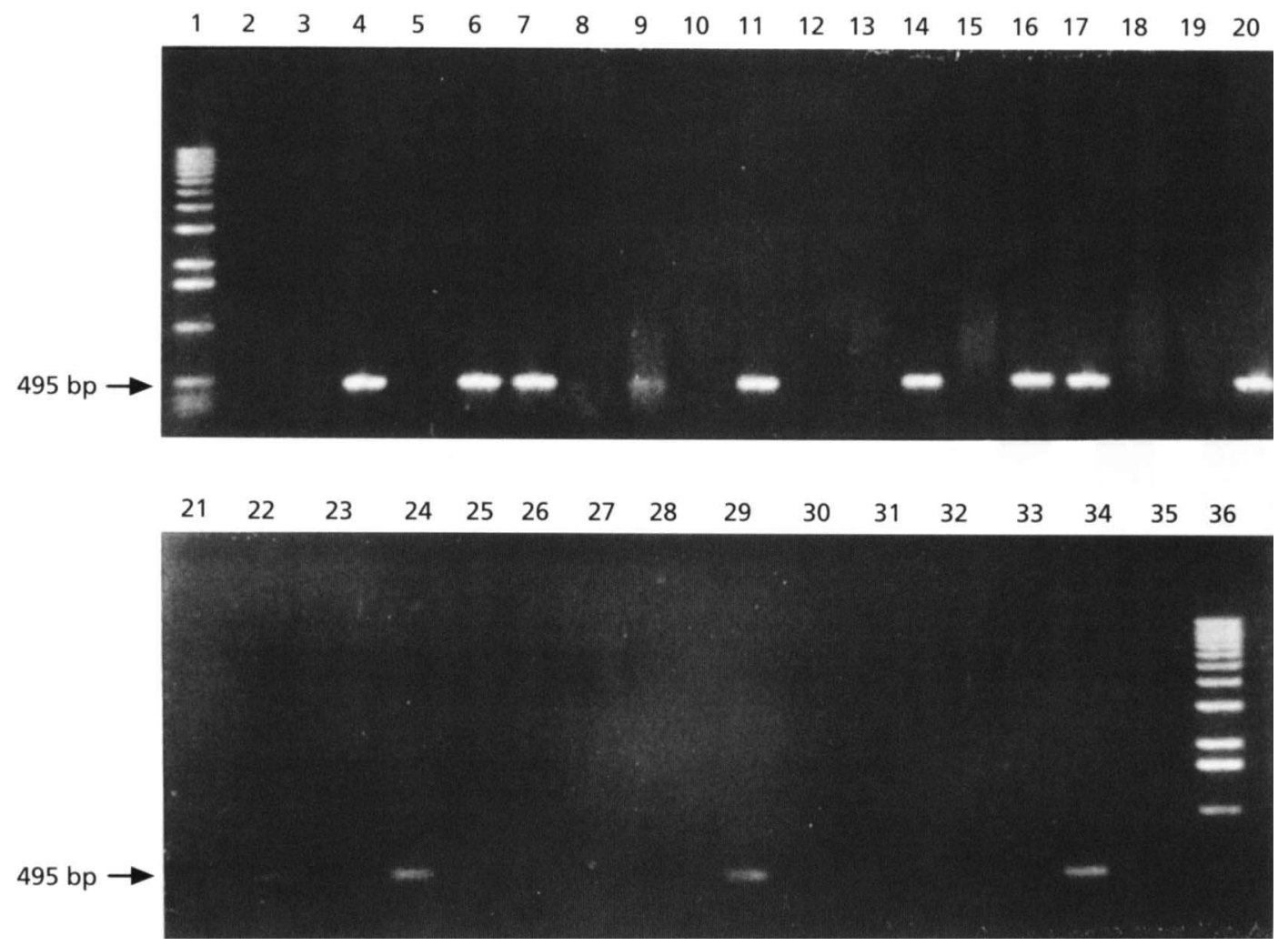

Fig. 5. PCR specificity with the different $M$. bovis and $M$. tuberculosis clinical isolates. Analysis of the PCR products obtained from cultured clinical isolates DNAs. Lanes: 1 and 36, $1 \mathrm{~kb}$ ladder molecular size markers; 20 and 34, positive control $M$. bovis ATCC 19210; 35, negative control without target DNA; 2, 3, 5, 8, 10, 12, 13, 15, 18, 19, 21, 23, 25, 26, 27, $28,30,31,32$ and 33, DNA from different $M$. tuberculosis isolates amplified with JB21-JB22 specific primers; 4, 6, 7, 9, 11, $14,16,17,22,24,29$, DNA from different $M$. bovis isolates amplified with JB21-JB22 specific primers, showing the 495 bp amplification fragment.

M. tuberculosis, M. bovis, M. bovis BCG, M. africanum and M. microti (Collins \& de Lisle, 1984, 1985), we were able to develop a new species-specific PCR assay capable of exclusively detecting $M$. bovis DNA.

In this study, a combination of two commonly used molecular biology techniques were applied for the identification of a species-specific genomic fragment of the $M$. bovis bacillus: the RAPD technique was used to obtain a fragment unique to $M$. bovis, which was then used to design primers for the highly sensitive DNA amplification technique of PCR (Saiki et al., 1988). The RAPD technique has been used previously for strain typing of several micro-organisms (Bassam et al., 1992; Jayarao et al., 1992), including M. tuberculosis (Palittapongarnpim et al., 1993). The approach described here allowed the differentiation of $M$. bovis from other mycobacterial species, and more importantly, from the strains belonging to the $M$. tuberculosis complex, which share more than a $90 \%$ homology at the DNA level (Imaeda, 1985).

Southern blot analysis using EcoRI-digested genomic DNA hybridized to the radiolabelled $500 \mathrm{bp}$ fragment obtained from $M$. bovis RAPD amplification revealed four fragments common to both the $M$. bovis and the $M$. tuberculosis genomes, indicating possible partial homo- logies, which confirms the close relationship between these two species. A strong $2900 \mathrm{bp}$ hybridization signal was observed only in the $M$. bovis genome, suggesting the presence of a polymorphic region that could also be used in a restriction pattern analysis. Whether this $500 \mathrm{bp}$ fragment is part of previously reported repetitive sequences (Thierry et al., 1990; Hermans et al., 1991) or is part of an intergenic region between these repeats is not yet known, but is under active investigation by our group.

The PCR assay using primers JB21 and JB22 clearly amplifies a fragment exclusively in the $M$. bovis genome. Detection of $M$. bovis by this assay can be carried out in a single step and thus presents an advantage over previous reports which involve an initial amplification step and the subsequent use of differential probes (Barry et al., 1993; Collins \& de Lisle, 1985) or restriction enzyme patterns (Hance et al., 1989). Due to the clumping phenomena, characteristic of mycobacteria, quantification of the number of mycobacteria in a test sample or spiked milk has not yet been performed. However, we were able to detect down to $10 \mathrm{fg}$ DNA, which corresponds roughly to two bacilli, accordingly to previous reports (Baess, 1984).

The specific PCR reported here can distinguish $M$. bovis 
from other mycobacteria, including the closely related species M. tuberculosis. On the other hand, this method can be used directly on biological samples such as milk making this a good assay for the rapid, specific and sensitive diagnosis of $M$. bovis. Early detection of $M$. bovis by PCR could be useful either as an epidemiological tool for field trials in cattle or in human clinical follow-up programmes, in order to establish the real magnitude of bovine tuberculosis.

\section{ACKNOWLEDGEMENTS}

We thank Tatiana Suarez for technical assistance and Daniel Garzon for providing us with the $M$. bovis isolates. We are grateful to Maria Mercedes Zambrano and Mario Posada for critical review of the manuscript. This work was supported by COLCIENCIAS under contract no. 011-93, the Ministry of Public Health of Colombia and the German Leprosy Relief Association.

\section{REFERENCES}

Baess, I. (1979). Deoxyribonucleic acid relatedness among species of slow-growing mycobacteria. Acta Pathol Microbiol Scand Sect B 87, 221-226.

Baess, I. (1983). Deoxyribonucleic acid relationships between different serovars of Mycobacterium avium, Mycobacterium intracellulare, and Mycobacterium scrofulaceum. Acta Patbol Microbiol Scand Sect B 91, 201-203.

Baess, I. (1984). Determination and re-examination of genome size and base ratio of deoxyribonucleic acid from mycobacteria. Acta Pathol Microbiol Scand Sect B 92, 209-211.

Baldino, F., Chesselet, M. F. \& Lewis, M. E. (1989). High resolution in situ hybridization histochemistry. Methods Enzymol 168, 761-777.

Barry, T., Glennon, M., Smith, T. \& Gannon, F. (1993). Detection of Mycobacterium bovis in bovine blood by combined PCR and DNA probe methods. Vet $\operatorname{Rec} 132,66-67$.

Bassam, B. J., Caetano-Anollés, G. \& Gresshoff, P. M. (1992). DNA amplification fingerprinting of bacteria. Appl Microbiol Biotechnol 38, 70-76.

Brett, J. L. \& Humble, M. W. (1991). Incidence of human tuberculosis caused by Mycobacterium bovis. NZ Med J 104, 13-14.

Collins, C. H. \& Grange, J. M. (1983). The bovine tubercle bacillus. J Appl Bacteriol 55, 13-29.

Collins, D. M. \& de Lisle, G. W. (1984). DNA restriction endonuclease analysis of Mycobacterium tuberculosis and Mycobacterium bovis BCG. J Gen Microbiol 130, 1019-1021.

Collins, D. M. \& de Lisle, G. W. (1985). DNA restriction endonuclease analysis of Mycobacterium bovis and other members of the tuberculosis complex. J Clin Microbiol 21, 562-564.

Cook, S. M., Bartos, R. E., Pierson, C. L. \& Frank, T. S. (1994). Detection and characterization of atypical mycobacteria by the polymerase chain reaction. Diagn Mol Pathol 3, 53-58.

Cormican, M. G. \& Flynn, J. (1992). Tuberculosis in the west of Ireland 1986-1990. Ir J Med Sci 161, 70-72.

Daniel, T. M. \& Janicki, B. W. (1978). Mycobacterial antigens: a review of the isolation, chemistry and immunological properties. Microbiol Rev 42, 84-113.

Del Portillo, P., Murillo, L. A. \& Patarroyo, M. E. (1991). Amplification of a species-specific DNA fragment of Mycobacterium tuberculosis and its possible use in diagnosis. J Clin Microbiol 29, 2163-2168.
Eisenach, K. D., Crawford, J. T. \& Bates, J. H. (1986). Genetic relatedness among strains of the Mycobacterium tuberculosis complex. Am Rev Respir Dis 133, 1065-1068.

Fifis, T., Plackett, P., Corner, L. A. \& Wood, P. R. (1989). Purification of a major Mycobacterium bovis antigen for the diagnosis of bovine tuberculosis. Scand J Immunol 29, 91-101.

Franco, R., Ruiz-Trevisan, A. \& Zorzopulos, J. (1989). Development of molecular probes for the diagnosis of mycobacteria. Rev Argent Microbiol 21, 146-148.

Griffin, J. F., Nagai, S. \& Buchan, G. S. (1991). Tuberculosis in domesticated red deer: comparison of purified protein derivative and the specific protein MPB70 for in vitro diagnosis. Res $V e t S c i$ 50, 279-285.

Haas, W. H., Butler, W. R., Woodley, C. L. \& Crawford, J. T. (1993). Mixed-linker polymerase chain reaction: a new method for rapid fingerprinting of isolates of Mycobacterium tuberculosis complex. $J$ Clin Microbiol 31, 1293-1298.

Hance, A. J., Grandchamp, B., Lévy-Frébault, V., Lecossier, D., Rauzier, J., Bocart, D. \& Giquel, B. (1989). Detection and identification of mycobacteria by amplification of mycobacterial DNA. Mol Microbiol 3, 843-849.

Harboe, M. \& Nagai, S. (1984). MPB70 a unique antigen of Mycobacterium bovis BCG. Am Rev Respir Dis 129, 444-452.

Harboe, M., Wiker, H. G., Duncan, J. R., Garcia, M. M., Dukes, T. W., Brooks, B. W., Turcotte, C. \& Nagai, S. (1990). Protein G-based enzyme linked immunosorbent assay for anti-MPB70 antibodies in bovine tuberculosis. J Clin Microbiol 28, 913-921.

Hermans, P. W. M., Van Sooningen, D., Bik, E. M., De Haas, P. E. W., Dale, J. W. \& Van Embden, J. D. A. (1991). Insertion element IS987 from Mycobacterium bovis BCG is located in a hotspot integration region for insertion elements in Mycobacterium tuberculosis complex strains. Infect Immun 59, 2695-2705.

Imaeda, T. (1985). Deoxyribonucleic acid relatedness among selected strains of Mycobacterium tuberculosis, Mycobacterium bovis, Mycobacterium bovis BCG, Mycobacterium microti and Mycobacterium africanum. Int J Syst Bacteriol 35, 147-150.

Jayarao, B. M., Bassam, B. J., Caetano-Anollés, G., Gresshoff, P. M. \& Oliver, S. P. (1992). Subtyping of Streptococcus uberis by DNA amplification fingerprinting. J Clin Microbiol 30, 1347-1350.

Karison, A. G. \& Carr, D. T. (1970). Tuberculosis caused by Mycobacterium bovis. Ann Intern Med 73, 979-983.

Maniatis, T., Fritsch, E. F. \& Sambrook, J. (1982). Molecular Cloning: a Laboratory Manual. Cold Spring Harbor, NY: Cold Spring Harbor Laboratory.

Mizrahi, V., Huberts, P., Dawes, S. S. \& Dudding, L. R. (1993). A PCR method for the sequence analysis of the $g y r A$, pol $A$ and $r n b A$ gene segments from mycobacteria. Gene 136, 287-290.

Noordhoek, G. T., Kolk, A. H., Bjune, G., Catty, D., Dale, J. W. \& Fine, P. E. (1994). Sensitivity specificity of PCR for detection of Mycobacterium tuberculosis: a blind compatison study among seven laboratories. J Clin Microbiol 32, 277-284.

Palittapongarnpim, P., Chomic, S., Fanning, A. \& Kunimoto, D. (1993). DNA fragment length polymorphism analysis of $M$. tuberculosis isolates by arbitrarily primed polymerase chain reaction. $J$ Infect Dis 167, 975-978.

Pan American Health Organization (1991). Health Conditions in the Americas, 1990, vol. 1. Scientific publication no. 524. Washington, DC: Pan American Health Organization.

Parra, C. A., Londofio, L. P., Del Portillo, P. \& Patarroyo, M. E. (1991). Isolation, characterization, and molecular cloning of a specific Mycobacterium tuberculosis antigen gene: identification of a species-specific sequence. Infect Immun 59, 3411-3417. 
Radford, A. J., Duffield, B. \& Plackett, P. (1988). Cloning of a species-specific antigen of Mycobacterium bovis. Infect Immun 56, 921-925.

Saiki, R. K., Gelfand, D. H., Stoffel, S., Scharf, S. J., Higuchi, R., Horn, G. T., Mullis, K. B. \& Erlich, H. A. (1988). Primer directed enzymatic amplification of DNA with a thermostable DNA polymerase. Science 239, 487-491.

Sanger, F., Nicklen, S. \& Coulson, A. R. (1977). DNA sequencing with chain terminating inhibitors. Proc Natl Acad Sci USA 74, 5463-5467.

Telenti, A., Marchesi, F., Balz, M., Bally, F., Bottger, E. C. \& Bodmer, T. (1993). Rapid identification of mycobacteria to the species level by polymerase chain reaction and restriction enzyme analysis. J Clin Microbiol 31, 175-178.

Thierry, D., Cave, M. D., Eisenach, K. D., Crawford, J. T., Bates,
J. H., Gicquel, B. \& Guesdon, J. L. (1990). IS6110, an IS-like element of Mycobacterium tuberculosis complex. Nucleic Acids Res 18, 188.

Welsh, J. \& McClelland, M. (1990). Fingerprinting genomes using PCR with arbitrary primers. Nucleic Acids Res 18, 7213-7218.

Williams, J. G. K., Kubelik, A. R., Livak, K. J., Rafalski, J. A. \& Tingey, S. V. (1990). DNA polymorphism amplified by arbitrary primers are useful as genetic markers. Nucleic Acids Res 18, 6531-6535.

Zainuddin, Z. F. \& Dale, J. W. (1989). Polymorphic repetitive DNA sequences in Mycobacterium tuberculosis detected with a gene probe from a Mycobacterium fortuitum plasmid. J Gen Microbiol 135, 2347-2355.

Received 11 April 1995; accepted 5 May 1995. 